\title{
First report of Trichodinella and new geographical records of trichodinids in Nile tilapia (Oreochromis niloticus) farmed in Brazil
}

\author{
Primeiro relato de Trichodinella e novos registros geográficos de tricodinídeos em tilapia do Nilo \\ (Oreochromis niloticus) cultivada no Brasil \\ Fabrício Sado Rodrigues ${ }^{1}$; Inácio Mateus Assane ${ }^{2,3}$; Gustavo Moraes Ramos Valladão ${ }^{4}$; Fernanda Gomes de Paula; \\ Caniggia Lacerda Andrade ${ }^{1}$; Anderson Pires de Moraes ${ }^{1}$; Mariana Dall’Agnol ${ }^{1}$; Lívia Mendonça Pascoal ${ }^{1 *}$ (D) \\ ${ }^{1}$ Escola de Veterinária e Zootecnia - EVZ, Universidade Federal de Goiás - UFG, Goiânia, GO, Brasil \\ ${ }^{2}$ Faculty of Agricultural Sciences, Zambeze University - UniZambeze, Ulónguè, Tete, Mozambique \\ ${ }^{3}$ Laboratório de Microbiologia e Parasitologia de Organismos Aquáticos, Centro de Aquicultura, Universidade Estadual Paulista - \\ UNESP, Jaboticabal, SP, Brasil \\ ${ }^{4}$ Universidade Nilton Lins, Manaus, AM, Brasil
}

Received November 20, 2018

Accepted March 19, 2019

\begin{abstract}
Massive occurrence of trichodinids is frequently accompanied by serious disease in fish farms. In this study, trichodinid species from the gills and skin of Nile tilapia (Oreochromis niloticus) farmed in the central-western region of Brazil (state of Goiás) were morphologically characterized. Dried slides were prepared from the parasites and were impregnated with silver nitrate (2\%). Morphometric characteristics were determined and schematic drawings of the denticles were made using photomicrographs produced from the slides. Seven species of trichodinid ectoparasites (Protozoa: Ciliophora: Trichodinidae) were found parasitizing the gills: four of the genus Trichodina Ehrenberg, 1838; one of Tripartiella Lom, 1959; one of Paratrichodina Lom, 1963; and one of Trichodinella Šrámek-HuS̆̉ek, 1953. On the body surface, three specimens of the genus Trichodina were identified. This study presents new geographical records of trichodinids in Brazil, thus confirming that Trichodina centrostrigeata, Trichodina compacta, Trichodina heterodentata, Paratrichodina africana and Tripartiella orthodens are widely distributed worldwide. Additionally, the first record of the genus Trichodinella in Brazil is presented.
\end{abstract}

Keywords: Trichodinids, trichodiniasis, parasite, taxonomy, aquaculture.

\section{Resumo}

O parasitismo intenso por tricodinídeos está frequentemente relacionado à doença grave em fazendas de peixes. Neste estudo, espécies de tricodinídeos das brânquias e da pele de tilápias do Nilo (Oreochromis niloticus) cultivadas na região centro-oeste do Brasil (estado de Goiás) foram caracterizadas morfologicamente. As lâminas secas foram preparadas a partir dos parasitas e impregnadas com nitrato de prata (2\%). As características morfométricas foram determinadas e desenhos esquemáticos dos dentículos foram confeccionados com fotomicrografias produzidas a partir das lâminas. Sete espécies de ectoparasitos tricodinídeos (Protozoa: Ciliophora: Trichodinidae) foram encontradas parasitando as brânquias: quatro do gênero Trichodina Ehrenberg, 1838; um de Tripartiella Lom, 1959; um de Paratrichodina Lom, 1963; e um de Trichodinella Šrámek-Huš̉ek, 1953. Na superfície do corpo, três espécimes do gênero Trichodina foram identificados. Este estudo apresenta novos registros geográficos de tricodinídeos no Brasil, confirmando que Trichodina centrostrigeata, Trichodina compacta, Trichodina heterodentata, Paratrichodina africana e Tripartiella orthodens estão amplamente distribuídas mundialmente. Adicionalmente, é apresentado o primeiro registro do gênero Trichodinella no Brasil.

Palavras-chave: Tricodinídeos, tricodiníase, parasita, taxonomia, aquicultura.

\footnotetext{
*Corresponding author: Lívia Mendonça Pascoal. Escola de Veterinária e 


\section{Introduction}

The prevalence and spread of diseases have become more and more important since aquatic food production has transitioned from being primarily based on catching wild fish to farming of increasing numbers of fish species (FAO, 2016). Captive fish and their parasites are routinely translocated around the world (BASSON \& VAN AS, 1994; REINERTSEN \& HAALAND, 1995; VALLADÃO et al., 2014), which may affect the health status of fish farms. Therefore, studies focusing on identifying parasites and their distribution are important.

Trichodinids are mobile peritrichous ciliated protozoa that are important within marine and inland aquaculture. More than 300 species of trichodinids have been recognized as parasites or symbionts of aquatic organisms (GONG et al., 2005; MITRA et al., 2013; MACIEL et al., 2018). They are perhaps the most frequent protozoa invading the surface of fish and have been implicated in severe disease and mortality in various parts of the world (NIKOLIĆ et al., 2003; KHAN, 2004; KHOSHNOOD \& KHOSHNOOD, 2014; VALLADÃO et al., 2014).

Considering the socioeconomic importance of Nile tilapia (Oreochromis niloticus) within Brazilian aquaculture and the economic impact of parasitic diseases, very little information on these groups is available. Only three out of the eleven genera of the family Trichodinidae have so far been reported parasitizing Nile tilapias in Brazil, namely Trichodina Ehrenberg, 1838 (Trichodina centrostrigeata Basson, Van As and Paperna, 1983, T. compacta Van As and Basson, 1989, T. heterodentata Duncan, 1977, T. magna Van As and Basson, 1989, T. migala Van As and Basson, 1989), Paratrichodina Lom, 1963 (Paratrichodina africana Kazubski and El-Tantawy, 1986) and Tripartiella Lom, 1959 (Tripartiella orthodens Basson and Van As, 1987) (GHIRALDELLI et al., 2006; MARTINS \& GHIRALDELLI, 2008; PANTOJA et al., 2012; VALLADÃO et al., 2013, 2016; ZAGO et al., 2014; NUNES et al., 2016).

Trichodinids are usually identified through the morphology of the denticles in the adhesive disc and the development of the adoral ciliary spiral, and the denticles have very high systematic value (GONG et al., 2005). Correct identification depends mainly on the quality of the impregnation and staining techniques that are used to evaluate these characteristics. Nevertheless, some trichodinids become impregnated less than others do, thus making it difficult to describe the species. Difficulties in evaluating the results from impregnation are commonly encountered in relation to Trichodinella Śrámek-Hus̆̉ek, 1953, in which the correct picture is sometimes misread as artefacts because of the insignificant dimensions of the denticles, which can easily become damaged when the smear preparation dries out (LOM, 1963). Although some species have a wide variety of hosts and geographical distributions (LOM \& HALDAR, 1977; BASSON \& VAN AS, 1987), there are very few records of these small trichodinids in the literature.

Nile tilapia are freshwater cichlids native to Africa. They are one of the most important farmed fish worldwide (FAO, 2016). They grow fast in different aquaculture systems and over a wide range of temperatures, and also have high market value (EL-SAYED, 2006; LIM \& WEBSTER, 2006). In Brazil, which ranks $13^{\text {th }}$ among the world's top aquaculture producers and second in the Americas (FAO, 2016), Nile tilapias were introduced into aquatic ecosystems in the 1970 s to improve fisheries and aquaculture (MOREIRA et al., 2007). Actually, this is the main species produced, representing more than $45 \%$ of all fish production (IBGE, 2015). The relationship between tilapia translocation and the spread of parasites in freshwater ecosystems has been documented by many authors (VAN AS \& BASSON, 1989; BONDAD-REANTASO \& ARTHUR, 1989). Trichodinids are the main protozoa associated with tilapia translocation worldwide.

In the present study, trichodinids from the gills and body of farmed Nile tilapia in a new geographical location, the central-western region of Brazil (state of Goiás), were identified and described.

\section{Materials and Methods}

\section{Study area and fish}

Specimens of $O$. niloticus (Supreme strain) were collected in June 2016, from floating net-cages in a reservoir at the fishery facilities of the Department of Animal Science of the School of Veterinary and Animal Sciences of the Federal University of Goiás, State of Goiás, central-western region of Brazil (16 $36^{\circ}$ ' 42" S; $49^{\circ} 16 ’ 52$ ” W).

The water quality parameters in the net-cages were measured during the fish sampling as follows (mean $\pm \mathrm{SD}$ ): the dissolved oxygen was $7.09 \pm 0.39 \mathrm{mg} \mathrm{L}^{-1}$; the temperature was $20.75 \pm 0.57^{\circ} \mathrm{C}$; the $\mathrm{pH}$ was $7.00 \pm 0.22$; and the ammonia content was $0.03 \pm 0.015 \mathrm{mg} \mathrm{L}^{-1}$. The dissolved oxygen and temperature were determined using a digital oxygen meter (AT 155; Alfakit Ltd.); the $\mathrm{pH}$ was determined using a digital $\mathrm{pH}$ meter (AT 315; Alfakit Ltd.) and the ammonia concentration was determined using a digital photo colorimeter (AT 100PBS II; Alfakit Ltd.).

The experimental procedures were approved by the Ethics and Animal Welfare Committee (CEUA) of the Federal University of Goiás, under protocol number 015/2016.

\section{Parasite diagnosis and taxonomic evaluation}

Eleven fish $(13.62 \mathrm{~g} \pm 1.78)$ were collected randomly from four net-cages $\left(0.7 \mathrm{~m}^{3}\right.$ useful volume and density of 300 fish per cage). They were desensitized through thermal shock in water with ice (proportion 1:1) and then euthanized via medullary sectioning to conduct a parasitological survey. Samples from the gills and body mucus were collected separately through scraping. The material thus collected was deposited on glass slides and was observed while fresh under an optical microscope (40, 100 and $400 \mathrm{x})$.

Slides containing parasites were air-dried and subsequently impregnated with silver nitrate $(2 \%)$ for evaluation of all their taxonomic characteristics (KLEIN, 1958). Measurements of the components of the adhesive discs and denticles were made as described by Arthur \& Lom (1984) and, additionally, the numbers of denticles and pins were counted. The measurements were made on photomicrographs $(1000 \mathrm{x})$ that were obtained using a Nikon ${ }^{\circledR}$ E200 optical microscope (Nikon Instruments Inc., Melville, United States) equipped with a Motic ${ }^{\circledR} 5.0$ image capture system (Motic Instruments Inc., Hong Kong, China). These measurements were presented in micrometers as suggested by Lom (1958) and Van As \& Basson (1989). All the measurements were made using the 
Image Pro Plus ${ }^{\circledR}$ software media (Cybernetics Inc, Rockville, United States). The measurement data thus obtained were presented as the mean \pm standard deviation (with minimum and maximum and the number of repetitions).

In order to describe the shape of the denticle, schematic drawings of the denticles were produced as proposed by Van As \& Basson (1989), by means of vectorization using the CorelDraw ${ }^{\circledR}$ X8 software (Corel Corporation, Ottawa, Canada).

\section{Results}

\section{Trichodinid description: from body}

The measurements of the taxonomic characteristics of each population of trichodinids collected from the body surface of the fish are presented in Table 1.

\section{Trichodina compacta}

The blade was large, filling most of the space between the $y$-axes. The anterior margin touched the y-axes and sometimes went slightly beyond it. A prominent apophysis was observed at the anterior margin of the blade. The central part extended to half of the space between the axes and had a rounded presentation. The connection between the central part and ray had uniform thickness and was similar to the ray. The rays were generally parallel to the $y$-axes with greater thickness, filling almost the entire space between the y-axes. The central circle was characteristic for the species, presenting scattered darker spots (Figure 1a).

\section{Trichodina heterodentata}

The blade was large and filled almost the entire space between the $y$-axes. The anterior portion of the blade went significantly beyond the limit of the y-axes. A prominent apophysis was common at the anterior margin of the blade. The central part extended to half of the space between the axes and had a rounded presentation. The ray had a prominent apophysis in its anterior

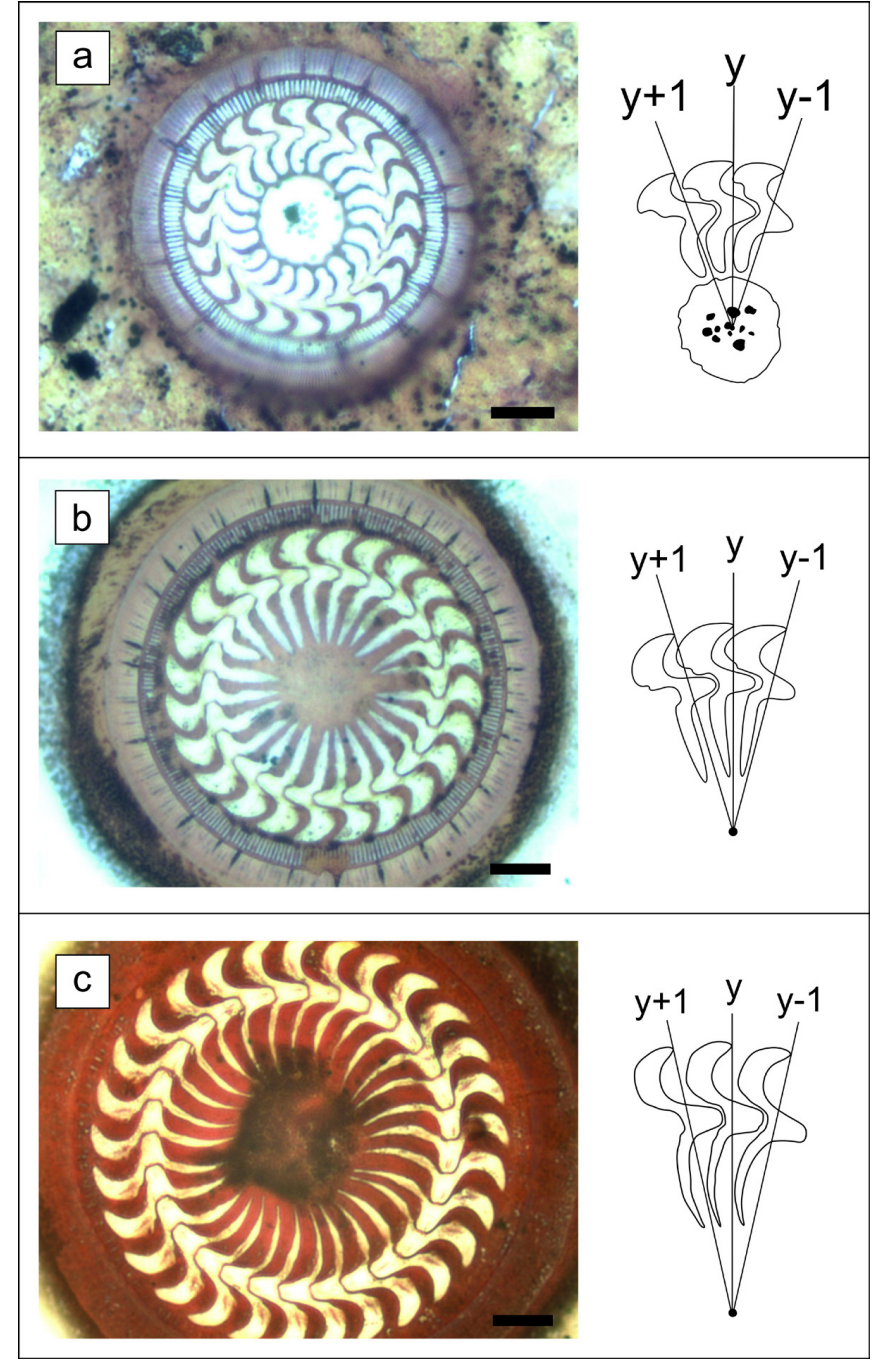

Figure 1. Photomicrographs of silver impregnated adhesive discs and schematic drawing of the denticles of Trichodina compacta (a); T. heterodentata (b) and T. magna (c) found in the body of Nile tilapia Oreochromis niloticus cultured in Central-West region of Brazil. Scale bars: $10 \mu \mathrm{m}$.

Table 1. Measurements of trichodinids from body of Nile tilapia Oreochromis niloticus. The data are presented as arithmetic mean \pm standard deviation (minimum-maximum values; number of individuals measured).

\begin{tabular}{|c|c|c|c|}
\hline Trichodinids species & Trichodina compacta & Trichodina heterodentata & Trichodina magna* \\
\hline Body diameter & $54.61 \pm 3.39(48.9-61.4 ; 22)$ & $70.10 \pm 6.15(60.2-79.8 ; 18)$ & 91.86 \\
\hline Border membrane & $4.57 \pm 0.47(3.4-5.2 ; 22)$ & $5.37 \pm 0.70(4.3-7.7 ; 18)$ & 7.86 \\
\hline Adhesive disc & $45.41 \pm 3.30(40.0-53.2 ; 22)$ & $59.41 \pm 6.14(49.1-69.2 ; 18)$ & 75.79 \\
\hline Denticulate ring & $28.19 \pm 2.71(23.5-34.4 ; 22)$ & $37.61 \pm 3.92(31.0-43.8 ; 18)$ & 49.56 \\
\hline Central circle & $13.75 \pm 1.73(10.4-18.0 ; 22)$ & - & - \\
\hline Denticle span & $11.86 \pm 0.73(10.8-13.1 ; 22)$ & $17.90 \pm 1.41(15.0-19.8 ; 18)$ & 24.41 \\
\hline Ray length & $4.91 \pm 0.55(4.1-5.9 ; 22)$ & $9.60 \pm 1.05(7.5-10.9 ; 18)$ & 13.10 \\
\hline Central part & $2.51 \pm 0.32(1.9-3.0 ; 22)$ & $2.66 \pm 0.32(2.1-3.3 ; 18)$ & 3.63 \\
\hline Blade length & $4.43 \pm 0.35(3.7-5.3 ; 22)$ & $5.55 \pm 0.62(4.2-6.7 ; 18)$ & 7.44 \\
\hline Denticle length & $8.23 \pm 0.56(7.2-9.4 ; 22)$ & $9.44 \pm 1.06(7.4-11.4 ; 18)$ & 10.09 \\
\hline Number of denticles & $19.29 \pm 0.96(18-21 ; 21)$ & $23.67 \pm 1.03(22-26 ; 18)$ & 29 \\
\hline Pins/denticle & $8.32 \pm 0.48(8-9 ; 22)$ & $10.76 \pm 0.90(10-12 ; 17)$ & \\
\hline
\end{tabular}

*Only one parasite well impregnated of this species was found in the present study. 
portion and its thickness varied from wider to thinner. The tip of the ray was sharp (Figure $1 \mathrm{~b}$ ).

\section{Trichodina magna}

This trichodinid had a large body size, compared with the other species. The denticle blade was tight, filling almost half of the space between the axes. The anterior margin of the blade was slightly flattened (straight) and did not touch the y-axes. The ray had a prominent apophysis. It was thin and curved, and pointed slightly in the anterior direction, but did not go beyond the y-axes (Figure 1c).

\section{Trichodinids description: from gills}

The measurements of the taxonomic characteristics of each population of trichodinids collected from the gills are presented in Table 2.

\section{Trichodina centrostrigeata}

The blade of the denticle was thin and the anterior and posterior margins were similar and almost parallel to each other. The blade filled a large portion of the space between the $y$-axes and its anterior margin went beyond the y-axes. The central part was short and rounded. The ray had uniform thickness with a sharp tip, positioned parallel or anteriorly to the y-axes, and sometimes going beyond them. This trichodinid had a central ridge that was characteristic for the species (Figure 2a).

\section{Trichodina compacta}

The morphological characteristics were similar to those described in specimens that were found on the body surface (Figure 2b).

\section{Trichodina heterodentata}

The morphological characteristics were similar to those described in specimens that were found on the body surface (Figure 2c).

\section{Trichodina migala}

The blade was thin and did not fill much of the space between the $y$-axes. The anterior portion did not touch the y-axes and, in some cases, a small apophysis was seen. The central part occupied more than half of the area between the y-axes. Ray apophyses were prominent. The ray was thin, curved, sharp and displaced in the anterior direction, sometimes going beyond the limit of the y-axes (Figure 2d).

Table 2. Measurements of trichodinids of from gills of Nile tilapia Oreochromis niloticus. The data are presented as arithmetic mean \pm standard deviation (minimum-maximum values; number of individuals measured).

\begin{tabular}{|c|c|c|c|c|c|c|c|}
\hline Characters & $\begin{array}{c}T . \\
\text { centrostrigeata }\end{array}$ & $\begin{array}{c}T . \\
\text { migala } \\
\end{array}$ & $\begin{array}{c}T . \\
\text { beterodentata }\end{array}$ & $\begin{array}{c}T . \\
\text { compacta }\end{array}$ & $\begin{array}{c}\text { Paratrichodina } \\
\text { africana }\end{array}$ & $\begin{array}{c}T . \\
\text { orthodens }\end{array}$ & $\begin{array}{c}\text { Trichodinella } \\
\text { sp. }\end{array}$ \\
\hline Body diameter & $\begin{array}{c}55.73 \pm 5.02 \\
(47.0-64.9 ; 22)\end{array}$ & $\begin{array}{c}76.01 \pm 5.66 \\
(70.5-83.6 ; 4)\end{array}$ & $\begin{array}{l}70.45 \pm 6.06 \\
(63.9-80.4 ; 9)\end{array}$ & $\begin{array}{c}53.09 \pm 2.20 \\
(49.9-57.9 ; 9)\end{array}$ & $\begin{array}{c}25.04 \pm 2.50 \\
(21.6-29.8 ; 20)\end{array}$ & $\begin{array}{c}27.36 \pm 1.35 \\
(24.9-29.1 ; 9)\end{array}$ & $\begin{array}{c}22.94 \pm 2.38 \\
(20.2-25.7 ; 6)\end{array}$ \\
\hline Border membrane & $\begin{array}{c}3.71 \pm 0.84 \\
(2.1-5.4 ; 22)\end{array}$ & $\begin{array}{l}5.67 \pm 0.50 \\
(5.1-6.2 ; 4)\end{array}$ & $\begin{array}{l}5.43 \pm 0.53 \\
(4.6-6.0 ; 9)\end{array}$ & $\begin{array}{l}4.61 \pm 0.53 \\
(3.6-5.4 ; 9)\end{array}$ & $\begin{array}{c}1.80 \pm 0.19 \\
(1.3-2.1 ; 20)\end{array}$ & $\begin{array}{l}2.50 \pm 0.31 \\
(1.8-2.9 ; 9)\end{array}$ & $\begin{array}{l}2.04 \pm 0.38 \\
(1.5-2.5 ; 6)\end{array}$ \\
\hline Adhesive disc & $\begin{array}{c}49.03 \pm 5.31 \\
(39.1-60.1 ; 23)\end{array}$ & $\begin{array}{c}64.71 \pm 6.83 \\
(57.7-73.7 ; 4)\end{array}$ & $\begin{array}{c}59.61 \pm 5.58 \\
(53.5-68.3 ; 9)\end{array}$ & $\begin{array}{c}44.35 \pm 2.09 \\
(42.0-49.1 ; 9)\end{array}$ & $\begin{array}{c}21.24 \pm 2.42 \\
(17.7-26.3 ; 20)\end{array}$ & $\begin{array}{c}22.36 \pm 1.34 \\
(19.8-24.2 ; 9)\end{array}$ & $\begin{array}{c}21.65 \pm 2.84 \\
(18.5-24.4 ; 6)\end{array}$ \\
\hline Denticulate ring & $\begin{array}{c}26.04 \pm 2.89 \\
(21.7-32.0 ; 24)\end{array}$ & $\begin{array}{c}40.79 \pm 5.50 \\
(35.8-48.5 ; 4)\end{array}$ & $\begin{array}{c}39.09 \pm 6.99 \\
(29.7-50.6 ; 10)\end{array}$ & $\begin{array}{c}27.13 \pm 2.13 \\
(25.2-32.3 ; 9)\end{array}$ & $\begin{array}{c}12.42 \pm 1.88 \\
(9.4-16.3 ; 20)\end{array}$ & $\begin{array}{l}10.88 \pm 0.88 \\
(9.3-12.5 ; 9)\end{array}$ & $\begin{array}{c}12.01 \pm 1.72 \\
(10.2-14.4 ; 6)\end{array}$ \\
\hline Central circle & - & - & - & $\begin{array}{c}13.11 \pm 1.66 \\
(10.7-16.1 ; 9)\end{array}$ & $\begin{array}{c}5.82 \pm 0.48 \\
(4.7-6.7 ; 20)\end{array}$ & $\begin{array}{l}7.42 \pm 0.73 \\
(6.3-8.5 ; 9)\end{array}$ & $\begin{array}{l}4.37 \pm 0.35 \\
(4.0-5.0 ; 6)\end{array}$ \\
\hline $\mathrm{N}$ of central ridges & $\begin{array}{c}13.22 \pm 1.93 \\
(10.0-17.0 ; 24)\end{array}$ & - & - & - & $\begin{array}{c}1.88 \pm 0.33 \\
(1.3-2.5 ; 20)\end{array}$ & $\begin{array}{l}1.91 \pm 0.23 \\
(1.5-2.2 ; 9)\end{array}$ & $\begin{array}{l}0.56 \pm 0.08 \\
(0.5-0.7 ; 5)\end{array}$ \\
\hline Denticle span & $\begin{array}{c}12.82 \pm 1.94 \\
(9.8-16.3 ; 24)\end{array}$ & $\begin{array}{c}18.48 \pm 2.02 \\
(15.8-20.2 ; 4)\end{array}$ & $\begin{array}{c}17.64 \pm 1.64 \\
(14.8-19.8 ; 10)\end{array}$ & $\begin{array}{c}11.80 \pm 0.87 \\
(10.9-13.7 ; 9)\end{array}$ & $\begin{array}{c}0.54 \pm 0.10 \\
(0.3-0.7 ; 20)\end{array}$ & $\begin{array}{l}0.54 \pm 0.06 \\
(0.4-0.6 ; 9)\end{array}$ & $\begin{array}{l}1.3 \pm 0.15 \\
(1.2-1.5 ; 5)\end{array}$ \\
\hline Ray length & $\begin{array}{c}4.57 \pm 0.98 \\
(2.5-6.7 ; 24)\end{array}$ & $\begin{array}{l}8.30 \pm 1.59 \\
(6.0-9.7 ; 4)\end{array}$ & $\begin{array}{c}9.61 \pm 1.33 \\
(7.3-11.6 ; 10)\end{array}$ & $\begin{array}{l}5.38 \pm 0.50 \\
(4.7-6.2 ; 9)\end{array}$ & $\begin{array}{c}3.33 \pm 0.27 \\
(2.7-3.8 ; 20)\end{array}$ & $\begin{array}{l}4.87 \pm 0.60 \\
(3.7-5.7 ; 9)\end{array}$ & $\begin{array}{l}2.34 \pm 0.47 \\
(1.7-2.8 ; 6)\end{array}$ \\
\hline Central part & $\begin{array}{c}2.42 \pm 0.54 \\
(1.4-3.3 ; 24)\end{array}$ & $\begin{array}{l}3.43 \pm 0.81 \\
(2.6-4.3 ; 4)\end{array}$ & $\begin{array}{c}2.46 \pm 0.27 \\
(2.1-3.0 ; 10)\end{array}$ & $\begin{array}{l}2.30 \pm 0.33 \\
(1.6-2.7 ; 9)\end{array}$ & $\begin{array}{c}2.42 \pm 0.39 \\
(1.7-3.4 ; 20)\end{array}$ & $\begin{array}{l}2.57 \pm 0.33 \\
(2.1-3.1 ; 9)\end{array}$ & $\begin{array}{l}2.21 \pm 0.28 \\
(1.9-2.6 ; 6)\end{array}$ \\
\hline Blade length & $\begin{array}{c}5.73 \pm 0.94 \\
(4.1-7.5 ; 24)\end{array}$ & $\begin{array}{l}6.56 \pm 0.87 \\
(5.3-7.2 ; 4)\end{array}$ & $\begin{array}{c}5.51 \pm 0.52 \\
(4.6-6.1 ; 10)\end{array}$ & $\begin{array}{l}4.12 \pm 0.51 \\
(3.5-4.9 ; 9)\end{array}$ & $\begin{array}{c}22.17 \pm 1.10 \\
(20-25 ; 18)\end{array}$ & $\begin{array}{c}21.44 \pm 1.01 \\
(20-23 ; 9)\end{array}$ & $\begin{array}{c}21.00 \pm 1.41 \\
(19-22 ; 5)\end{array}$ \\
\hline Denticle length & $\begin{array}{c}4.51 \pm 0.37 \\
(3.8-5.3 ; 24)\end{array}$ & $\begin{array}{l}8.53 \pm 0.48 \\
(8.0-9.0 ; 4)\end{array}$ & $\begin{array}{c}9.00 \pm 1.03 \\
(7.1-10.7 ; 10)\end{array}$ & $\begin{array}{l}8.16 \pm 0.51 \\
(7.5-8.9 ; 9)\end{array}$ & - & $\begin{array}{c}5 \pm 0 \\
(5-5 ; 1)\end{array}$ & - \\
\hline $\begin{array}{l}\text { Number of } \\
\text { denticles }\end{array}$ & $\begin{array}{c}27.71 \pm 1.00 \\
(26-30 ; 24)\end{array}$ & $\begin{array}{c}27.00 \pm 1.41 \\
(26-29 ; 4)\end{array}$ & $\begin{array}{c}23.90 \pm 2.08 \\
(22-28 ; 10)\end{array}$ & $\begin{array}{c}19.00 \pm 0.76 \\
(18-20 ; 8)\end{array}$ & $\begin{array}{c}25.04 \pm 2.50 \\
(21.6-29.8 ; 20)\end{array}$ & $\begin{array}{c}27.36 \pm 1.35 \\
(24.9-29.1 ; 9)\end{array}$ & $\begin{array}{c}22.94 \pm 2.38 \\
(20.2-25.7 ; 6)\end{array}$ \\
\hline Pins/denticle & $\begin{array}{c}9.33 \pm 1.15 \\
(8-10 ; 3)\end{array}$ & $\begin{array}{l}10.00 \pm 0 \\
(10-10 ; 4)\end{array}$ & $\begin{array}{c}10.40 \pm 1.14 \\
(9-12 ; 5)\end{array}$ & $\begin{array}{c}8.89 \pm 1.05 \\
(8-10 ; 9)\end{array}$ & $\begin{array}{c}1.80 \pm 0.19 \\
(1.3-2.1 ; 20)\end{array}$ & $\begin{array}{l}2.50 \pm 0.31 \\
(1.8-2.9 ; 9)\end{array}$ & $\begin{array}{l}2.04 \pm 0.38 \\
(1.5-2.5 ; 6)\end{array}$ \\
\hline
\end{tabular}




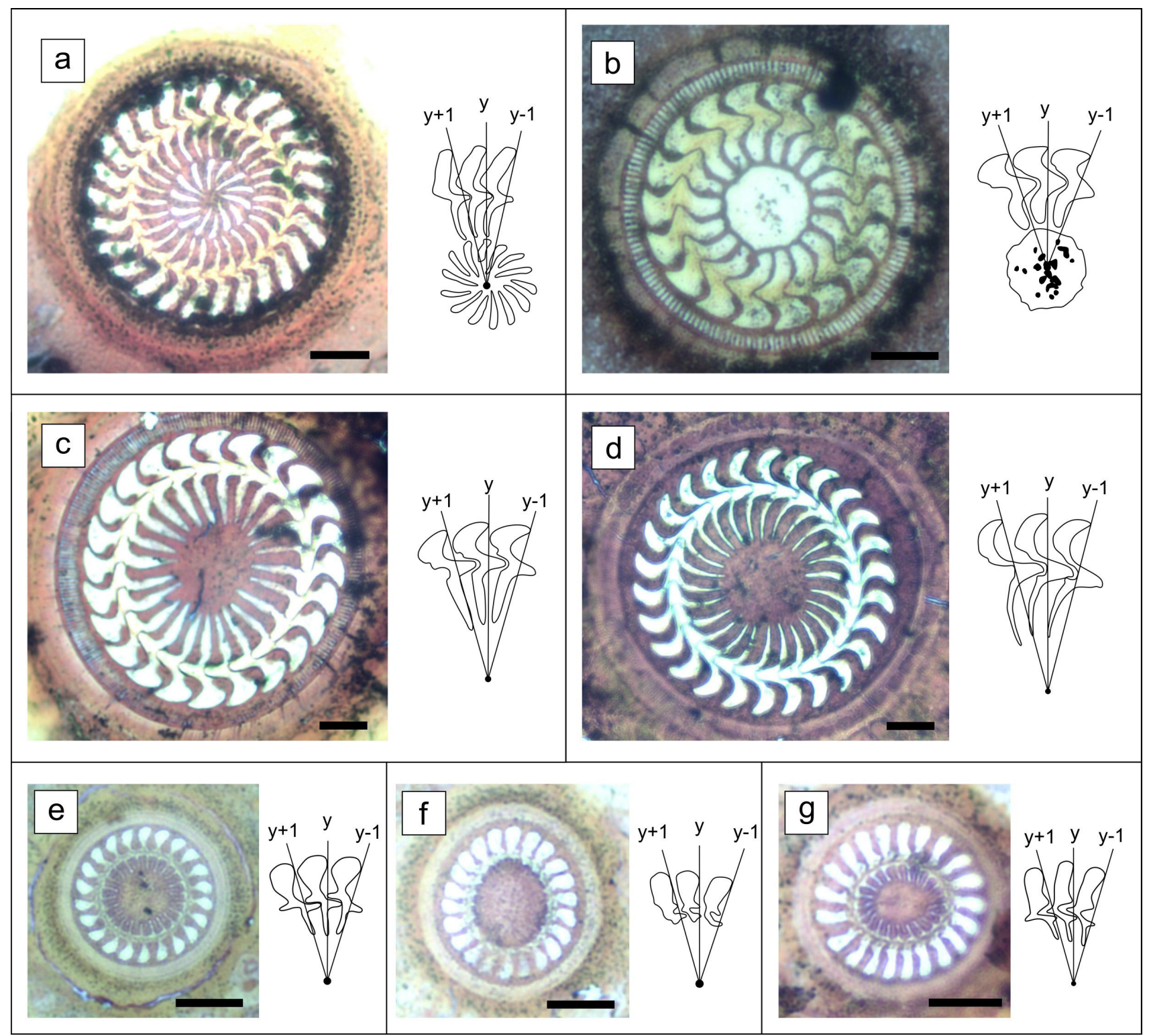

Figure 2. Photomicrographs of silver impregnated adhesive discs and schematic drawing of the denticles of Trichodina centrostrigeata (a); T. compacta (b); T. heterodentata (c); T. migala (d); Paratrichodina africana (e); Trichodinella sp. (f) and Tripartiella orthodens (g) found in the gills of Nile tilapia Oreochromis niloticus cultured in Central-West region of Brazil. Scale bars: $10 \mu \mathrm{m}$.

\section{Paratrichodina africana}

This trichodinid had a rounded blade that was not sickle-shaped, thus differing from the genus Trichodina. The central part had a large and characteristic elongated part that was parallel to the central part of the adjacent denticle. The central part was thin, rounded and filled about half of the space between the y-axes. The ray was thin, with the rounded tip lying parallel to the $y$-axes (Figure 2e).

\section{Trichodinella sp.}

This trichodinid was difficult to impregnate because of its small size and minute denticle. The blade had a small projection and the anterior margin extended well into the space between the y-axes. The central part was delicate, short and did not go beyond the y-axis. The denticles were small and inserted together in the central parts and projections, which made it difficult to see them in the silver-impregnated specimens. The ray formed a characteristic short delicate curved hook (Figure 2f).

\section{Tripartiella orthodens}

This was a small-sized trichodinid. The anterior margin of the blade was straight and the posterior margin was rounded. In the posterior portion, this trichodinid had a prominent projection. In the anterior portion, between the blade and the central part, another prominent projection was observed, which went beyond the y-axes. The central part was small 
and occupied a small portion of the space between the y-axes. The ray was straight, with similar thickness up to its tip, and it was parallel to or was positioned slightly posteriorly to the $\mathrm{y}$-axis (Figure $2 \mathrm{~g}$ ).

\section{Discussion}

In the present study four genera of trichodinids were found parasitizing Nile tilapia cultivated in Brazil: Trichodina (T. centrostrigeata, T. compacta, T. heterodentata, T. magna and T. migala), Paratrichodina (P. africana), Tripartiella (T. orthodens) and Trichodinella (Trichodinella sp.). All the trichodinids identified from this study have an African origin (BASSON et al., 1983; BASSON \& VAN AS, 1987, 1994; VAN AS \& BASSON, 1989). However, they have also been found parasitizing fish in the Americas (AGUILAR-AGUILAR \& ISLAS-ORTEGA, 2015) and in Eurasia (DUNCAN, 1977; BASSON \& VAN AS, 1994; MITRA \& HALDAR, 2004; MITRA \& BANDYOPADHYAY, 2006; MITRA et al., 2012; MOHILAL \& HEMANANDA, 2012).

In Brazil, there have also been records of $T$. centrostrigeata in the southeastern region (VALLADÁO et al., 2016) and in the northern region (BITTENCOURT et al., 2014); T. compacta in the southern region (GHIRALDELLI et al., 2006) and southeastern region (VALLADÃO et al., 2016); T. heterodentata in the southern region (MARTINS et al., 2010) and southeastern region (VALLADÁO et al., 2016); T. magna in the southern region (MARTINS \& GHIRALDELLI, 2008) and southeastern region (ZAGO et al., 2014); T. migala in the southeastern region (VALLADÃO et al., 2016); P. africana in the southern region (GHIRALDELLI et al., 2006; JERÔNIMO et al., 2011), southeastern region (VALLADÃO et al., 2016), northern region (BITTENCOURT et al., 2014) and northeastern region (VALLADÃO et al., 2013); and T. orthodens in the southeastern region (VALLADÃO et al., 2016). In the present study, trichodinids were identified in the central-western region of Brazil (state of Goiás) and the first record of the genus Trichodinella in this country was presented.

The trichodinids in this study has a very constant denticle shape that became impregnated well with silver nitrate, although in some species the denticles were somewhat less impregnated, thus making it difficult to identify them (Paratrichodina, Tripartiella and Trichodinella). The morphometric and morphological characteristics of $T$. centrostrigeata, $T$. compacta, $T$. heterodentata, T. magna, T. migala, P. africana and T. orthodens that were identified in the present study were similar to those in previous descriptions of these species in Nile tilapias in Brazil. Nevertheless, the body diameter of T. heterodentata was slightly larger (64-80 versus 38-59) than those reported by Valladão et al. (2016), but was similar to those described by Duncan (1977) (64-80 versus 58-122). We consider that small differences are common, since variability in morphometric and morphological characteristics of trichodinids has been observed in other populations of these protozoa (LOM, 1958). Such differences usually relate to the developmental stages of the denticle, the host and the environmental conditions (DUNCAN, 1977; GONG et al., 2005).
The genus Trichodinella was described by Lom (1963) as having one incomplete turn of the two adoral ciliary rows in the adoral zone, a peculiarly shaped denticle and small dimensions, and was reported as only parasitizing the gills of fish. So far, about eight species have been identified from marine and freshwater organisms. The Trichodinella sp. from this study was collected from the gills and due to its small size and the minuteness of the denticles, the impregnation was not good enough to perform species identification. However, some elements of their structure, e.g. body diameter, border membrane, adhesive disc, denticulate ring, denticle span, denticle ray, central part of the denticle and blade, were fairly well preserved in the preparations. These enabled comparisons with other small trichodinids that have already been described in the literature.

The Trichodinella sp. of the present study seems to be identical to the species identified by Lom (1963) as Trichodinella epizootica S̆rámek-Huš̉ek, 1953, which occurs in the gills of different species of fish on the Eurasian continent. All the measurements of taxonomic characteristics relating to that species are very close to those of Trichodinella sp. in the present study. The measurements of our specimens are also similar to the T. epizootica populations of Basson et al. (1983) from Cyprinus carpio; of Albaladejo \& Arthur (1989) from Cyprinus carpio; of Al-Rasheid et al. (2000) from Mormyrus kannume; of Mitra \& Haldar (2004) from Puntius gelius; and of Basson (2010) from Tinca tinca.

In the literature, schematic drawings of T. epizootica vary significantly between each description (Figure 3). The schematic drawing of Trichodinella sp. identified here was very similar to the record of Mitra \& Haldar (2004) (Figure 3). These differences may be due to the common variations observed in T. epizootica morphology within the same population or in populations from different hosts (LOM, 1963; LOM \& HALDAR 1977; BASSON \& VAN AS, 1987; BASSON, 2010). These variations occur mainly due to difficulties in impregnation with silver nitrate, which culminates in different interpretations by different authors. Furthermore, Figure 3 shows that the schematic drawing of T. epizootica described by Al-Rasheid et al. (2000) is quite similar to the schematic drawing of Trichodinella carpi Duncan, 1977, from Tang et al. (2005). These presented more similarities than between the records of T. epizootica. Measurement data and schematic drawings indicate that the parasite of our study may be of the species T. epizootica. However, due to the small number of well-impregnated specimens and the confusion in the literature, we have only described the genus.

The present investigation has extended the distribution area of identified trichodinid species to the central-western region of Brazil and has added one more country to the checklist of Trichodinella distribution around the world. These findings confirm that $T$. centrostrigeata, $T$. compacta, $T$. heterodentata, $P$. africana and $T$. orthodens are widely distributed worldwide, occurring in various habitats. So far, Trichodinella appears to be rare in Brazil, but this may only be because researchers' interest in identifying trichodinids down to species level is comparatively recent and because of the small sizes of these species, which make it difficult to identify them even when they have been impregnated with silver nitrate. 

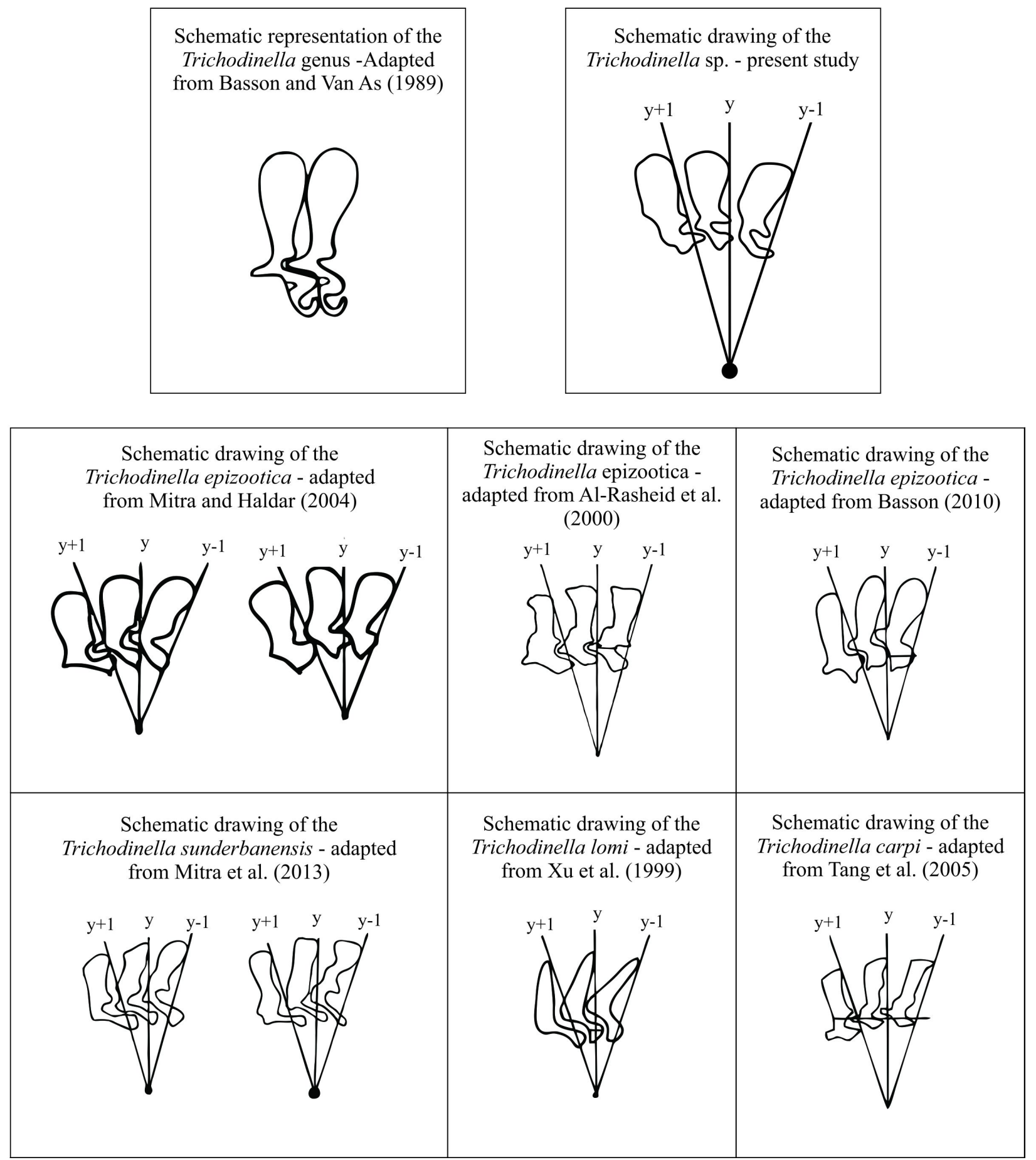

Figure 3. Schematic drawing of the denticles of Trichodinella demonstrating the diversity of denticle shape among Trichodinella epizootica (redrawn from various sources: BASSON \& VAN AS, 1989; MITRA \& HALDAR, 2004; AL-RASHEID et al., 2000; BASSON, 2010; MITRA et al., 2013; XU et al., 1999 and TANG et al., 2005).

\section{Acknowledgements}

This research was funded by Coordination of top-level staff development (CAPES) and Foundation for Research Promotion of the State of Goiás (FAPEG). The authors would like to thank staff from fishery facilities of the Department of Animal Science of the School of Veterinary and Animal Sciences of the Federal University of Goiás, Piscicultura Aquabel and VB Alimentos.

\section{References}

Aguilar-Aguilar R, Islas-Ortega AG. A checklist of ciliate parasites (Ciliophora) of fishes from Mexico. Zootaxa 2015; 4027(2): 270-280. http://dx.doi.org/10.11646/zootaxa.4027.2.6. PMid:26624179.

Albaladejo JD, Arthur JJR. Some trichodinids (Protozoa: Ciliophora: Peritrichida) from freshwater fishes imported into the Philippines. Asian Fish Sci 1989; 3: 1-25. 
Al-Rasheid KA, Ali MA, Sakran T, Abdel Baki AA, Abdel Ghaffar FA. Trichodinid ectoparasites (Ciliophora: Peritrichida) of some River Nile fish, Egypt. Parasitol Int 2000; 49(2): 131-137. http://dx.doi.org/10.1016/ S1383-5769(00)00042-8. PMid:10882902.

Arthur JR, Lom J. Trichodinid Protozoa (Ciliophora: Peritrichida) from freshwater fishes of Rybinsk reservoir, USSR. J Protozool 1984; 31(1): 82-91. http://dx.doi.org/10.1111/j.1550-7408.1984.tb04294.x.

Basson L. First records of trichodinid ectoparasites (Ciliophora: Peritrichia) from introduced freshwater fishes in Tasmania, Australia, with comments on pathogenicity. Acta Protozool 2010; 49(3): 253-265.

Basson L, Van As JG. Trichodinid (Ciliophora; Peritricha) gill parasites of freshwater fish in South Africa. Syst Parasitol 1987; 9(2): 143-151. http://dx.doi.org/10.1007/BF00012192.

Basson L, Van As JG. Differential diagnosis of the genera in the family Trichodinidae (Ciliophora: Peritrichida) with the description of a new genus ectoparasitic on freshwater fish from southern Africa. Syst Parasitol 1989; 13(2): 153-160. http://dx.doi.org/10.1007/BF00015224.

Basson L, Van As JG. Trichodinid ectoparasites (Ciliophora: Peritrichida) of wild and cultured freshwater fishes in Taiwan, with notes on their origin. Syst Parasitol 1994; 28(3): 197-222. http://dx.doi.org/10.1007/ BF00009518.

Basson L, Van As JG, Paperna I. Trichodinid ectoparasites of cichlid and cyprinid fishes in South Africa and Israel. Syst Parasitol 1983; 5(4): 245-257. http://dx.doi.org/10.1007/BF00009159.

Bittencourt LS, Pinheiro DA, Cárdenas MQ, Fernandes BM, Tavares-Dias M. Parasites of native Cichlidae populations and invasive Oreochromis niloticus (Linnaeus, 1758) in tributary of Amazonas River (Brazil). Rev Bras Parasitol Vet 2014; 23(1): 44-54. http://dx.doi.org/10.1590/S198429612014006. PMid:24728360.

Bondad-Reantaso MG, Arthur JR. Trichodinids (Protozoa: Ciliophora: Peritrichida) of Nile tilapia (Oreochromis niloticus) in the Philippines. Asian Fish Sci 1989; 3(1): 27-44.

Duncan BL. Urceolariid Ciliates, including three new species, from cultured Philippine fishes. Trans Am Microsc Soc 1977; 96(1): 76-81. http://dx.doi.org/10.2307/3225966. PMid:403647.

El-Sayed AFM. Tilapia culture. London: CABI Publishing; 2006. http:// dx.doi.org/10.1079/9780851990149.0000.

Food and Agriculture Organization of the United Nations - FAO. The state of world fisheries and aquaculture: contributing to food security and nutrition for all. Rome: FAO; 2016.

Ghiraldelli L, Martins ML, Adamante WB, Yamashita MM. First record of Trichodina compacta Van As and Basson, 1989 (Protozoa: Ciliophora) from cultured Nile tilapia in the State of Santa Catarina, Brazil. Int J Zool Res 2006; 2(4): 369-375. http://dx.doi.org/10.3923/ijzr.2006.369.375.

Gong Y, Yu Y, Feng W, Shen Y. Phylogenetic relationships among Trichodinidae (Ciliophora: Peritricha) derived from the characteristic values of denticles. Acta Protozool 2005; 44(3): 237-243.

Intituto Brasileiro de Geografia e Estatistica - IBGE. Produçäo da pecuária municipal [online]. 2015 [cited 2018 Nov 20]. Available from: https:// ww2.ibge.gov.br/home/estatistica/economia/ppm/2015/default.shtm

Jerônimo GT, Speck GM, Cechinel MM, Gonçalves ELT, Martins ML. Seasonal variation on the ectoparasitic communities of Nile tilapia cultured in three regions in southern Brazil. Braz J Biol 2011; 71(2): 365-373. http://dx.doi.org/10.1590/S1519-69842011000300005. PMid:21755153.
Kazubski SL, El-Tantawy SAM. The ciliate Paratrichodina africana sp. n. (Peritricha, Trichodinidae) from Tilapia fish (Cichlidae) from Africa. Acta Protozool 1986; 25(4): 433-438.

Khan RA. Disease outbreaks and mass mortality in cultured Atlantic cod, Gadus morhua L., associated with Trichodina murmanica (Ciliophora). J Fish Dis 2004; 27(3): 181-184. http://dx.doi.org/10.1111/j.13652761.2004.00525.x. PMid:15009245.

Khoshnood Z, Khoshnood R. Histopathological effects of trichodiniasis in farmed freshwater Rainbow trout, Oncorhynchus mykiss in West of Iran. Int Sch Sci Res Innov 2014; 8(10): 1154-1157.

Klein BM. The "dry" silver method and its proper use. J Protozool 1958; 5(2): 99-103. http://dx.doi.org/10.1111/j.1550-7408.1958.tb02535.x.

Lim C, Webster CD. Tilapia: biology, culture, and nutrition. Boca Raton: CRC Press; 2006.

Lom J. A contribution to the systematics and morphology of endoparasitic trichodinids from amphibians, with a proposal of uniform specific characteristics. J Protozool 1958; 5(4): 251-263. http://dx.doi. org/10.1111/j.1550-7408.1958.tb02563.x.

Lom J. The ciliates of the family Urceolariidae inhabiting gills of fishes (the Trichodinella-group). Acta Soc Zool Bohemoslov 1963; 27: 7-19.

Lom J, Haldar DP. Ciliates of the genera Trichodinella, Tripartiella and Paratrichodina (Peritricha, Mobilina) invading fish gills. Folia Parasitol 1977; 24(3): 193-210.

Maciel PO, Garcia F, Chagas EC, Fujimoto RY, Tavares-Dias M. Trichodinidae in commercial fish in South America. Rev Fish Biol Fish 2018; 28(1): 33-56. http://dx.doi.org/10.1007/s11160-017-9490-1.

Martins ML, Ghiraldelli L. Trichodina magna Van As and Basson, 1989 (Ciliophora: Peritrichia) from cultured Nile tilapia in the state of Santa Catarina, Brazil. Braz J Biol 2008; 68(1): 169-172. http://dx.doi. org/10.1590/S1519-69842008000100024. PMid:18470393.

Martins ML, Marchiori N, Nunes G, Rodrigues MP. First record of Trichodina heterodentata (Ciliophora: Trichodinidae) from channel catfish, Ictalurus punctatus cultivated in Brazil. Braz J Biol 2010; 70(3): 637-644. http://dx.doi.org/10.1590/S1519-69842010000300022. PMid:20730352.

Mitra AK, Bandyopadhyay P. First record of ectoparasitic African Trichodinids (Ciliophora: Peritrichida) in a cichlid fish Oreochromis mossambicus (Peters 1852) from the Churni river system, West Bengal, India. Anim Biol Leiden Neth 2006; 56(3): 323-333. http://dx.doi. org/10.1163/157075606778441912.

Mitra AK, Bandyopadhyay PK, Gong Y, Bhowmik B. Occurrence of Trichodinid Ciliophorans (Ciliophora: Peritrichida) in the freshwater fishes of the river Churni with description of Trichodina glossogobae sp. nov. in West Bengal, India. J Parasit Dis 2012; 36(1): 34-43. http:// dx.doi.org/10.1007/s12639-011-0073-0. PMid:23542238.

Mitra AK, Bandyopadhyay PK, Gong Y, Goswami M, Bhowmik B. Description of two new species of ectoparasitic Trichodina Ehrenberg, 1830 (Ciliophora: Trichodinidae) from freshwater fishes in the river Ganges, India.J Parasit Dis 2013; 37(1): 35-41. http://dx.doi.org/10.1007/ s12639-012-0126-z. PMid:24431538.

Mitra AK, Haldar DP. First record of Trichodinella epizootica (Raabe, 1950) Śrámek-Huš̀ek, 1953, with description of Trichodina notopteridae sp. n. (Ciliophora: Peritrichida) from freshwater fishes of India. Acta Protozool 2004; 43: 269-274.

Mohilal N, Hemananda T. Record of the species of Tripartiella (Lom, 1959) from fishes of Manipur. J Parasit Dis 2012; 36(1): 87-93. http:// dx.doi.org/10.1007/s12639-011-0088-6. PMid:23542123. 
Moreira AA, Hilsdorf AWS, Silva JV, Souza VR. Variabilidade genética de duas variedades de tilápia nilótica por meio de marcadores microssatélites. Pesqui Agropecu Bras 2007; 42(4): 521-526. http://dx.doi.org/10.1590/ S0100-204X2007000400010.

Nikolić V, Simonović P, Poleksić V. Preference of trichodinids (Ciliata, Peritrichia) occurring on fish-pond carp for particular organs and some morphological implications. Acta Vet 2003; 53(1): 41-46. http://dx.doi. org/10.2298/AVB0301041N.

Nunes GC, Jerônimo GT, Vicente LRM, Madi RR, Valladão GMR, Martins ML. Trace elements and parasitism in Nile tilapia farmed in the Southern Brazil. Bol Inst Pesca 2016; 42(3): 578-589. http://dx.doi. org/10.20950/1678-2305.2016v42n3p578.

Pantoja W, Neves L, Dias M, Marinho R, Montagner D, Tavares-Dias M. Protozoan and metazoan parasites of Nile tilapia Oreochromis niloticus cultured in Brazil. Rev Mvz Cordoba 2012; 17(1): 2812-2819. http:// dx.doi.org/10.21897/rmvz.248.

Reinertsen H, Haaland H. Sustainable fish farming. Boca Raton: CRC Press; 1995.

Tang FH, Zhao YJ, Tang AK. Presence of ectoparasitic trichodinids (Ciliophora, Oligohymenophorea, Peritrichida) on the gills of cultured freshwater fish, Carassius auratus in Chongqing, China, with the description of a new species of the genus Trichodina. Acta Zootaxon Sin 2005; 30: 35-40.
Valladão GMR, Alves LO, Pilarski F. Trichodiniasis in Nile tilapia hatcheries: diagnosis, parasite:host-stage relationship and treatment. Aquaculture 2016; 451: 444-450. http://dx.doi.org/10.1016/j.aquaculture.2015.09.030.

Valladão GMR, Gallani SU, Pádua SB, Martins ML, Pilarski F. Trichodina heterodentata (Ciliophora) infestation on Prochilodus lineatus larvae: a host-parasite relationship study. Parasitology 2014; 141(5): 662-669. http://dx.doi.org/10.1017/S0031182013001480. PMid:24476792.

Valladão GMR, Pádua SB, Gallani SU, Menezes-Filho RN, Dias-Neto J, Martins ML, et al. Paratrichodina africana (Ciliophora): a pathogenic gill parasite in farmed Nile tilapia. Vet Parasitol 2013; 197(3-4): 705710. http://dx.doi.org/10.1016/j.vetpar.2013.04.043. PMid:23731856.

Van As J, Basson L. A further contribution to the taxonomy of the Trichodinidae (Ciliophora: Peritrichia) and a review of the taxonomic status of some fish ectoparasitic trichodinids. Syst Parasitol 1989; 14(3): 157-179. http://dx.doi.org/10.1007/BF02187051.

Xu K, Song W, Warren A. Trichodinid ectoparasites (Ciliophora: Peritrichida) from the gills of cultured marine fishes in China, with the description of Trichodinella lomi n. sp. Syst Parasitol 1999; 42(3): 219227. http://dx.doi.org/10.1023/A:1006067005936. PMid:10613540.

Zago AC, Franceschini L, Garcia F, Schalch SHC, Gozi KS, Silva RJ. Ectoparasites of Nile tilapia (Oreochromis niloticus) in cage farming in a hydroelectric reservoir in Brazil. Rev Bras Parasitol Vet 2014; 23(2): 171178. http://dx.doi.org/10.1590/S1984-29612014041. PMid:25054495. 